\title{
7. Testing times: the problem of 'history' in the Howard Government's Australian citizenship test
}

\author{
Gwenda Tavan
}

In 2007, the Howard Coalition Government introduced significant changes to Australian citizenship laws, including an extension of the residency requirements for applicants, a tightening of the English-language provisions and a test in which applicants needed to demonstrate their knowledge of Australian values and customs. According to the government, such measures were necessary to ensure the successful integration of migrants into the host society, to protect the Australian 'way of life' and to reinforce the fact that Australian citizenship was a privilege not a right. When Immigration Minister, Kevin Andrews, introduced the bill into Parliament, he claimed:

The test will encourage prospective citizens to obtain the knowledge they need to support successful integration into Australian society. The citizenship test will provide them with the opportunity to demonstrate in an objective way that they have the required knowledge of Australia, including the responsibilities and privileges of citizenship, and a basic knowledge and comprehension of English. ${ }^{1}$

The proposals inspired significant public debate, particularly about the merits of a citizenship test. The government was no doubt buoyed by opinion polls suggesting a majority of Australians supported the introduction of a test. ${ }^{2}$ Still, considerable public concern was expressed about its intent and possible effects. A summary of the written submissions in response to the government's discussion paper, which was released in September 2006, revealed that while a majority of individuals supported the implementation of the test, more than two-thirds of the organisations that responded were opposed to it. ${ }^{3}$ Many of these were community groups involved in migrant welfare and settlement. They questioned the practicality of the test, arguing its complexity would inhibit rather than encourage migrants to apply for citizenship. Many critics interpreted the reforms as one more government attempt to wind the clock back to the bad old days of the White Australia Policy and the infamous 'dictation test'. In January 2008, less than three months after the citizenship test was formally introduced, and amid reports of high failure rates, especially among non-English-speaking migrants and refugees, the new Rudd Labor Government commissioned a review of the changes introduced by its predecessor. ${ }^{4}$ In November 2008 , it announced 
that it would dump the Howard version of the test, 'replacing it with a new, simpler test based on Australia's democratic values rather than obscure historical or sporting facts'. 5

This chapter considers the role of history and memory in the introduction of the Howard Government's citizenship test. It identifies the processes of public, political and institutional remembering enacted in its construction, the interests and values this use of history serves and the practical and symbolic effects it has had. I argue that the test was a consciously constructed form of collective memory making that sought to reinforce a homogenous and undifferentiated view of Australian society and history in the pursuit of specific ideological and political interests. The 'memory politics' embedded in the test exemplify Brändström et al.'s warnings of the potentially 'constraining' use of history in public policy making when such a use serves to 'narrow' rather than 'broaden' a government's definition of the problem at hand (in this case, the presumed inadequacy of citizenship and integration policies in Australia) and the range of policy options it can draw on to deal with that problem. ${ }^{6}$

\section{The Howard reforms: return to a cultural-normative model of citizenship}

The Howard Government's citizenship reforms began on 1 July 2007 with the introduction of the Australian Citizenship Act 2007. Its provisions include, inter alia, a doubling of the residence requirements for citizenship to four years and new language requirements for employer-sponsored temporary business visas. The Australian Citizenship Amendment (Citizenship Testing) Bill 2007 followed, passed by Parliament on 12 September 2007. The test itself was formally implemented on 1 October $2007 .^{7}$

The act provides that applicants for citizenship must successfully complete a test before making an application for citizenship to demonstrate that they meet the requisite criteria of an understanding of the nature of their application, a basic knowledge of the English language and an adequate knowledge of the responsibilities and privileges of Australian citizenship. The act allows exemptions for some people, including those under the age of eighteen or over the age of sixty, and 'those with a permanent physical or mental incapacity which prevents them from understanding the nature of the application'. Provision is also made for some people, who do not have the necessary literacy skills required, to sit a verbal rather than a written test. ${ }^{8}$ The original test format was computer based, consisting of 20 multiple-choice questions randomly selected from a much larger pool. Questions aimed to test applicants' 'basic knowledge of English...knowledge of Australia and the responsibilities and privileges of citizenship'. Potential applicants were advised that the test would include 
questions on Australian history, geography, values, the Australian people and the system of government. ${ }^{9}$

The government justified the introduction of the test on the grounds that it would enhance the integration of immigrants and thereby contribute to meeting present and future immigration challenges. These challenges were always vaguely defined, though many critics linked them to the Howard Government's repeated public criticisms, after the 11 September 2001 terrorist attacks in the United States, of elements within the Muslim community for failing to integrate, and the government's longstanding belief that multicultural policies were a threat to national cohesion and stability. In its discussion paper, Australian citizenship: much more than a ceremony, released in September 2006, the government expressed the view that continuing large-scale immigration had significant implications for social stability and national identity:

[T] he challenge we will face as a nation will be to ensure the effective integration of new migrants into the Australian community and to foster a strong commitment to and identification with Australia regardless of their background. ${ }^{10}$

Underlying this concern about migrant integration was the government's commitment to reaffirming a culturally normative model of Australian citizenship, centred on notions of shared values, a cohesive 'national identity' and allegiance to the nation-state. This was not a new commitment for the Howard Government. In August 1998, Immigration Minister, Philip Ruddock, had announced the formation of the Australian Citizenship Council. Its objectives were to provide advice on appropriate ways to mark the fiftieth anniversary of Australian citizenship, and to seek 'advice on how we can further enhance Australian citizenship as not only the unifying force but also the symbol at the very heart of what being Australian is all about'. ${ }^{11}$ In its response to the council's 2001 report, Australian Citizenship for a New Century, the government reiterated its belief that 'more can be made of Australian citizenship, as a unifying concept, particularly by extending the focus to shared civic values in addition to the legal status of Australian citizenship'. 'Australian citizenship,' it reminded readers, 'is a common bond at the heart of a unified and inclusive Australia and it is our shared civic values that underpin Australian citizenship, in both the broad and legal sense and serve to unify us as a nation.' ${ }^{12}$

In the lead-up to the introduction of the test in 2007, the government affirmed the association of citizenship with issues of national identity and allegiance. According to the 2006 discussion paper, 'Australian citizenship is the single most unifying force...It lies at the heart of our national identity - giving us a strong sense of who we are and our place in the world. ${ }^{13}$ One of the principal stated aims of the reforms was to enhance the status and prestige of citizenship, and by implication that of the nation itself, by making it more difficult to attain. 
Much of the campaigning surrounding the reforms focused on 'values', English language and integration into a 'way of life'. In the booklet Becoming an Australian Citizen, which potential citizens were encouraged to read carefully before sitting the test, the claim was made that modern citizenship 'rests on sentiments of nationhood and enduring attachment to what Australians hold in common'. With this in mind,

new citizens are expected to have a basic knowledge of English. They are also expected to know something of Australia's history and heritage, our land and its people, and of the unique national culture which has evolved in Australia over time. ${ }^{14}$

This cultural-nationalist model proved to be problematic in a number of ways. It overshadowed the civic and democratic dimensions of Australian citizenship, as defined in the pages of the citizenship booklet on which the testing of applicants was based. Migrants were urged to embrace specific liberal democratic institutions and principles such as parliamentary democracy and the rule of law, as well as 'values' such as peacefulness, tolerance, compassion for those in need and freedom of religion, association and speech. These were presented, however, as uniquely 'Australian' characteristics rather than universal or civic principles. Notably absent was a discourse pertaining to the rights and responsibilities of 'free citizens' or the limits of the powers of the State in regard to those citizens. Rather, the citizenship bargain offered to prospective applicants comprised certain 'privileges' and 'responsibilities' to be bestowed by the State in return for settlers' declarations of loyalty and their ability to pass a test. ${ }^{15}$ 'Allegiance' to the nation-state was a central feature of Australian citizenship policy and discourse throughout much of the twentieth century, giving way only gradually to a more civic definition during the 1980s and 1990s. ${ }^{16}$ The introduction of the test, and Howard's broad package of citizenship reforms, aimed to reaffirm this allegiance model.

Another problem with the Howard model was that it encouraged an excessive reliance on self-referential, nebulous, highly contested and ultimately facile descriptors of national uniqueness. Their relevance and appeal to new settlers were always doubtful. For example, the citizenship booklet offered an extended discussion of the significance of various national symbols, including the flag, the national anthem, the national colours, Australia's floral emblem, the coat of arms and the national gemstone. ${ }^{17}$ Critics rightly pointed out that 'good citizenship' depended on a lot more than due reverence for the wattle and the opal, or knowing which Australian was most famous for playing cricket. ${ }^{18}$

A similar self-absorption surrounded the discussion of national values and characteristics - for example, the importance of 'mateship': 
Australia has a strong tradition of mateship - where people help and receive help from others voluntarily, especially in times of adversity. A mate can be a spouse, partner, brother, sister, daughter, son or a friend. A mate can also be a total stranger. ${ }^{19}$

New settlers would be forgiven for expressing confusion about this most 'Australian' of characteristics - how it manifests itself in concrete, everyday terms, how such an attitude is learned or how it differs from Christian principles of charity or radical traditions of fraternity and egalitarianism.

Also questionable was the assumption that 'testing' applicants for knowledge of customs and values would tangibly improve people's commitment to those values as opposed to just extracting procedural obedience. This approach reinforces the administrative aspects of the reforms and the key role that immigration officials played in the introduction of the test, backed up by the Prime Minister's previously publicly stated concern about the absence of an 'institution or code [which] lays down a test of Australianness' ${ }^{20}$ In this respect, the introduction of the test can be interpreted as a statist-nationalist managerialist practice in which one group's ownership of the national and political space is asserted through its ability to control the behaviour and outlook of a group not considered to be part of the national community. ${ }^{21}$ The physical 'act' of administrative compliance embodied in the test has been as significant as the content of the test itself in affirming the unequal power relationship that exists between the (foreign-born) 'out group' and the (white, British, Australian-born) 'in group', which has the power to demand obedience (the latter, of course, is not compelled to sit a test to prove its 'loyalty' and 'knowledge'). As a letter to the Age pointed out, 'The citizenship test should stay. This test is to find out how much people do know. Make it hard, keep it hard, a test is a test. ${ }^{22}$

\section{The citizenship test as a form of collective memory making (and forgetting)}

History plays a fundamental role in nationalist discourse, creating the myths of origins by which national communities maintain a sense of unique identity and cohesion. This history, nevertheless, is always inherently contested, requiring selective forms of remembering and forgetting to maintain the facade of national homogeneity and cohesion. As Paula Hamilton puts it:

[D]efining groups or nations always necessitates a dual process of inclusion and exclusion and remembering the past is a central mechanism of that process. Many have noted that forgetting is one of the most powerful forces that shape national remembering. ${ }^{23}$

Jeffrey Olick and Joyce Robbins reinforce this point, drawing on Renan's famous dictum, 'national identities combine remembering and forgetting, with greater 
emphasis on the latter: They forget that they are not inevitable and that their internal fissures may be as significant as their external boundaries' ${ }^{24}$

This preoccupation with history and the highly contested narratives it gave rise to was duly manifested in the decision to test citizenship applicants on their knowledge of Australian history, and in the specific historical narratives that eventually emerged within the framework of the citizenship testing booklet. Prime Minister Howard was a fierce cultural warrior, defending the nation's conservative-liberal and British-imperial heritage and strongly criticising what he saw as a 'black-armband' view of history, which denigrated those achievements and overemphasised evidence of conflict, injustice and inequality in Australia's past. He strongly advocated a return to linear, narrative history to counter what he perceived as blatant (left-wing and progressive) ideological biases of thematic-based history. ${ }^{25}$

This intervention into cultural matters was not a new phenomenon, but continued a long tradition of prime ministerial concern with issues of national identity. ${ }^{26}$ It also perpetuated the long-held belief in Australia that by virtue of their control of immigration and citizenship policies, bureaucrats and political leaders were the principal gatekeepers of the imagined national community. As Alastair Davidson observes:

From its first formal statement of what it is to be a citizen in Australia, the Australian state has made it clear that its primary concern was to establish in a country of immigration that the newcomers show clearly that they have adopted a national identity, that they have joined the national family of British descent. ${ }^{27}$

Nevertheless, the Howard era was distinct for the extent of governmental interference in the cultural-nationalist arena, which included an (ill-fated) attempt to dictate the content of history teaching in schools. ${ }^{28}$ It focused ultimately on the question of migration, citizenship and identity, and the development of the history section of the citizenship booklet, Becoming an Australian Citizen.

Howard and his supporters argued that knowledge of Australian history was fundamental to the social and cultural integration of new settlers. They did not acknowledge, however, that specific political and ideological interests, and highly selective forms of remembering and forgetting, shaped this history. In an illuminating article, eminent historian John Hirst reveals his involvement in the writing of the history section of the booklet, after challenging the government's original version, which he describes as 'appallingly bad'. ${ }^{9}$ The basis for Hirst's claim was that the emphasis on narrative had led to

all the standard events and developments [being]...present in chronological order but so severely compacted that they were often no more than a list. You could read right through it and have no sense of 
the particular characteristics of Australian society; you would simply be overwhelmed by disconnected information...Quite strangely, for a book for newcomers, it frequently assumed knowledge of the subjects it treated-or rather mentioned. ${ }^{30}$

Hirst's offer to assist with the history section was accepted by officials within the Immigration Department, as was his recommendation that a themes-based approach be adopted. Ultimately, he professed 'little ground for complaint' with what eventually emerged, claiming that the Prime Minister's office 'signed off on a history which was not John Howard's, and was organised contrary to his declared preference for narrative'. ${ }^{31}$ Hirst also admits, however, to a significant degree of interference by 'departmental, ministerial and prime ministerial players' in creating and approving the history. He criticises Howard, not for intervening, but for the fact that 'having intervened he did not know when to stop'. ${ }^{32}$

The manoeuvres surrounding the preparation of the history section attest to the ideologically and politically charged nature of the enterprise. Hirst's confidence about the quality of the finished work notwithstanding, it is difficult not to interpret it as a victory for Howard and his conservative-nationalist supporters. Its central themes and the discursive strategies of which it was constituted showed this narrative to have been much more than just a 'history for migrants' and a resource to assist integration. More significant was its function of providing powerful affirmation to an imagined (white, British) Australian-born audience, whose core identity was perceived to be under threat. This was manifested in the essentially monocultural and undifferentiated view of the national community it presented, privileging white, male, 'British-Australian' institutions, values and endeavours through a focus on issues such as convict settlers, 'a harsh country', diggers and the Anzac legend, the economy and politics, sport and the nation.

Such privileging served to marginalise the place of various groups in the national story, including women, the working class, Indigenous and non-Anglo Australians. They were reduced to bit players, the beneficiaries of white, British-Australian, masculine endeavour rather than historical agents in their own right, whose own unique experiences, identities and memories were integral components of the national narrative. Issues of difference, conflict and power between groups were suppressed or treated superficially to sustain the view of national homogeneity and stability. This was most evident in the citizenship booklet's account of Aboriginal people, which occupied a bare two pages (diggers and the Anzac legend received three pages), and where controversial issues such as land rights, the Stolen Generations, reconciliation and the military intervention in NT communities were downplayed. ${ }^{33}$ Hirst himself admitted that officials removed some of his more sensitive comments regarding Indigenous-settler 
interactions on the frontier, the Stolen Generations and the plight of traditional people on their own lands in favour of more optimistic assessments. ${ }^{34}$

The suppression of the more problematic aspects of Australian history aimed to confirm the confident assertion in the citizenship booklet that Australia in the twenty-first century was 'a nation at ease with the world and with itself' ${ }^{35}$ There were audible silences nevertheless, conscious omissions that hinted at deep, continuing uncertainties about national identity and social cohesion. They reflect the continuing unsettling legacy of Australia's colonial heritage - in particular, the continuing failure of non-Indigenous Australia to come to terms with the dispossession and the continuing exploitation of Indigenous Australians. They belie repeated claims by the former government that during the Howard years Australians were finally 'relaxed and comfortable' about their identity and their past. ${ }^{36}$

There were other forms of historical forgetting at work in the citizenship test. One of the most troubling aspects was the decision to tighten English-language restrictions through formal testing. This was justified on the grounds that language skills were fundamental to good citizenship. It was also hoped this provision would provide 'incentives' for people to improve their English skills. Critics, in contrast, argued from the outset that the test would unfairly disadvantage people of non-English-speaking backgrounds and that too much emphasis was being given to English as a core requirement for citizenship (as opposed to a rights-based conception of citizenship that would privilege political knowledge and commitment to the body politic). While the centrality of English-language skills to structural integration is undisputed, it is difficult to see how a test in itself can possibly improve such skills. Claims of the commitment to improving English skills would have been more credible if they had been backed up with tangible efforts to improve funding and access to English classes.

The legitimacy of the new English-language requirements also depended on a fundamental act of historical amnesia. As Liberal MP Petro Georgiou-one of the few members within Coalition ranks to criticise the policies - pointed out, the language requirements were much tougher than anything Australia had in the past, and would be failed by thousands of people today, including the many native-born Australians who have poor literacy skills, and postwar immigrants from southern Europe with poor English who were nevertheless able to take out citizenship in the past. ${ }^{37}$ The latter were the same people who were often lauded by the Howard Government as the type of exemplary citizens newer groups should try to emulate. ${ }^{38}$ The self-evident contradictions of such claims were never openly addressed: that it is possible to be a good citizen and have poor English skills, and that non-English-speaking people have indeed played a fundamental role in the creation of the modern Australian nation-state. 
A form of historical forgetting was also enacted in praising these earlier groups of migrants without acknowledging that they too had often been the focus of public derision for not assimilating well or fast enough. This fact did not fit well with popular narratives that celebrated the enormous success of the postwar immigration program, the basis for which lay partly, one suspects, in the need to justify the contemporary immigration program, the scale of which grew significantly during the Howard decade. They also suggest a desire to ignore the historical truth of migrant inequality and injustice during the much-idealised 'long boom' years of the 1950s and 1960s, and nostalgia perhaps, among social conservatives, for the cultural certainties of an earlier assimilationist era.

Finally, as I further discuss below, embodied in the citizenship test was a tangible neglect of flawed policy initiatives throughout the twentieth century that discriminated against specific racial and ethnic groups in the name of national cohesion and identity, and which served to inhibit rather than enhance the integration process for migrants despite the apparent best intentions of policy makers.

\section{Historical analogies: citizenship policy in 'assimilationist Australia'}

One of the most striking aspects of the Howard Government's citizenship policies and discourse was how closely they echoed the anxieties and concerns, and the failed policies, of an earlier era of immigration and citizenship history. It is by now well known that until the late 1960s Australian citizenship was an overwhelmingly cultural-racial model, conceptualised primarily in relation to (white) British-Australian culture and ethnicity, rather than civic and democratic values. ${ }^{39}$ This manifested itself in a variety of racially exclusionary practices, including Australia's first officially sanctioned 'test' of assimilability, courtesy of the Immigration Restriction Act 1901 and the dictation test. ${ }^{40}$

This cultural-racial model remained in place long after the introduction of mass European immigration in 1947. While non-English-speaking Europeans were eventually determined to be acceptable as immigrants, non-Europeans continued to face major restrictions on entry until the early 1970s. Entry for all non-Britons was premised on the principle that they would speedily assimilate into Australian society and culture. Blatant discrimination and inequalities continued to exist in relation to Australian citizenship, based on racial and ethnic/cultural criteria. The Nationality and Citizenship Act 1948 defined an alien as 'a person who is not a British subject, an Irish citizen or protected person' ${ }^{41}$ British subjects did not have to take out Australian citizenship and were eligible to vote after six months' residence. European migrants could access voting rights only after becoming citizens and had to fulfil a five-year residency criterion. Non-Europeans were generally denied citizenship until 1956-57 and, after that, had to fulfil a 15-year residency criterion as distinct from the five-year rule for Europeans. 
Indigenous Australians were British subjects and Australian citizens but were denied many basic rights, including voting rights, reaffirming the extent to which ideas of race and culture shaped assumptions of social membership. ${ }^{42}$

Because of the cultural assumptions that underpinned it, citizenship remained the most fundamental indicator of a migrant's successful assimilation into the national community. A lot of effort was expended during the postwar years in encouraging migrants to take up citizenship: through the creation of elaborate citizenship ceremonies, through direct appeals and through the annual Australian Citizenship Conventions, which brought bureaucrats and political and community leaders together to discuss how best to achieve assimilation and to sell the citizenship message. 'Every migrant a citizen' was a common catchphrase at such forums, confirming the belief of successive governments that migrant settlement should be permanent and required political as well as social and cultural integration. Migrants were constantly entreated to 'help make Australia great'. Citizenship education campaigns urged migrants to embrace the 'Australian way of life'. 43

There were, nevertheless, strong tensions between successive governments' desire that immigrants settle permanently and embrace citizenship, and their belief that citizenship should be viewed as a privilege rather than a right - a prize that had to be earned rather than a cheap giveaway. Immigration officials actually contemplated the introduction of a formal test in 1945, on the grounds that it would

ascertain whether an applicant had an adequate knowledge of English, had some acquaintance of Australian history, form of government etc, was favourably disposed to our ideals and outlook and was genuinely desirous of becoming a citizen of this country. ${ }^{44}$

Such a method, it was hoped, would 'tend to impress more strongly upon applicants the seriousness and importance of naturalisation' ${ }^{45}$

A formal test was ultimately not adopted, most likely because of the enormous procedural complexities involved. Nevertheless, quite cumbersome administrative procedures for gaining citizenship existed. They included:

- a five-year residency criterion for Europeans (as opposed to one year for British subjects)

- lodgment of a Declaration of Intention to Apply for Naturalisation two years before the launch of the formal procedure for acquiring citizenship

- publication of an applicant's intention to become a citizen in two local newspapers

- three certificates of character written by Australian citizens

- knowledge of English (though that meant perfunctory knowledge only)

- renunciation of allegiance to the country of origin 
- no formal test, but an informal one for English language and knowledge of Australian customs and institutions.

These procedures did little to encourage the embrace of citizenship. In 1952, only 29000 of a possible 180000 eligible adult migrants had taken out citizenship. Approximately only 52 per cent had applied by $1960 .{ }^{46}$ Continuing research by the Immigration Department during the 1950s and 1960s revealed that the low take-up rate was attributable to a number of factors:

- prospective applicants, especially those with poor English skills, were discouraged by the complicated administrative procedures

- immigrants were not sure they wanted to stay permanently

- many immigrants were unwilling to renounce their allegiance to countries of origin

- citizenship was said to offer very few tangible benefits, other than voting rights and access to welfare

- some immigrants argued that citizenship would do little to enhance their social and economic position in society.

The message was clear. As Ann-Mari Jordens points out, citizenship for migrants involves an analysis of costs and benefits - a fact that postwar political leaders and bureaucrats were slow to realise. Despite the generous offer of citizenship, a sizeable proportion of migrants could discern no tangible advantage in making the leap. ${ }^{47}$ The complex administrative arrangements did little to encourage take-up rates. Government leaders had likewise failed to confront a fundamental truth about assimilation: that it was a complex and contested process influenced by a range of personal, cultural and structural factors; that individuals possessed a measure of agency in regard to questions of identity, participation and belonging; and that state-driven approaches to these issues did not necessarily achieve the desired results. Clearly, the opportunity to participate in the 'Australian way of life' was not enough to counter the structural inequities and social marginalisation many migrants experienced during that period. Many were unwilling to renounce their own distinct former loyalties and 'collective memories' in pursuit of Australian national membership. ${ }^{48}$ This included the many British migrants who failed to take up citizenship despite its ready availability to them.

Migrant resistance to assimilation and demands for a more equitable 'citizenship bargain', growing concerns about low citizenship take-up rates and increasing competition from other countries seeking migrants led over time to the liberalisation of settlement and citizenship policies. During the 1950s and 1960s, the most cumbersome procedural requirements were gradually removed. In the mid-1960s, the government initiated a shift away from assimilation policies towards an integrationist model that expanded provision of services for migrants. 
The five-year residence requirement for Europeans was lowered to three years in 1973. Ethnic and racial discrimination in immigration policy was gradually abolished and the final phase of the ending of the White Australia Policy was enacted in 1973. Citizenship rights for British and other migrants were also equalised that year. The requirement that citizens renounce their former allegiance was abolished in 1986. Multicultural policies and discourses sought to address sources of migrant inequality and better integrate migrant settlers into the national story.

Altogether, these initiatives constituted a fundamental challenge to the once dominant cultural-racial and administrative model of Australian citizenship and signalled the emergence of a new regimen more closely attuned to issues of civic and democratic rights and responsibilities. Due largely to these initiatives, until recently, Australia could boast of some of the most inclusive and generous immigration and citizenship policies in the developed world. Citizenship rates during the 1990s were 'spectacular', according to social scientists Brian Galligan and Winsome Roberts, with the 2001 census recording that approximately 95 per cent of eligible permanent residents had become citizens, compared with about 50 per cent in the 1960s. ${ }^{49}$ The significance of such numbers in terms of the wellbeing of migrants, Australia's social stability and its appeal as a destination for migrants should not be underestimated.

\section{Policy constraints and the political uses of immigration history}

There are a number of interesting parallels between Howard's citizenship test and the citizenship regime of the postwar assimilationist era. These include a definition of citizenship based on cultural absorption into an imagined homogenous social whole, the demand for allegiance to the nation-state and administrative complexity. Such parallels prompt the question of why the government and its supporters were so willing to pin their hopes on a model that had already proved to be a failure. Furthermore, why were they so disdainful of Australia's own proud, pioneering role in regard to citizenship policy from the late 1960s onwards?

It is not evident whether policy makers consciously knew of and ignored the precedents of the postwar period, including the doomed recommendation of the mid-1940s that formal testing be applied. Specific interests and values, however, clearly undermined any substantive engagement with this aspect of Australia's history, and thus any attempt to draw lessons from it. These interests related partly to the role of the bureaucracy in the reforms - that is, those members of the Department of Immigration whose brief it was to review Australia's citizenship provisions and who instigated an examination of international practices as part of that process. Much was made in the original discussion paper and subsequent related publications of the fact that 'many other countries' had 
formal testing procedures and were 'well ahead' in implementing their ideas. 50 The countries referred to most often were the United States, Canada, the United Kingdom and the Netherlands.

As Sue Wright points out, the practice of citizenship testing is growing in some parts of the world, raising important questions about the 'timing and scale' of this development - namely, why, when immigration is by no means a new phenomenon, so many states are formalising their citizenship arrangements and consolidating 'integration' efforts. No tangible evidence exists to prove that formal testing methods for citizenship achieve superior results in terms of assisting the integration process; testing content and procedures are not applied uniformly and many countries seem to manage quite well without formal testing. ${ }^{51}$

Various explanations have been offered to explain this apparent paradox, including the growth of anti-migrant and anti-Muslim sentiment and fears for national security in the post-11 September global environment, and popular resistance in developed economies to the contemporary scale of international migration. The renewed emphasis on citizenship and integration policies can be seen as part of a general tendency among sovereign states in the developed world to consolidate control over immigration intakes - legal and illegal - in the face of unprecedented global population movements, alongside stricter regulations of domestic entry, harsher sanctions against unauthorised entry and increased participation in international and intra-governmental arrangements to control migration flows. ${ }^{52}$

Another related factor is 'convergence', whereby strong similarities are increasingly evident in the policies of diverse states towards immigration and citizenship issues. The forces driving policy convergence are multifaceted but include the phenomenon of trans-governmentalism, whereby 'political networks are becoming more transnational and their members share knowledge and experience' ${ }^{53}$ The introduction of the Australian citizenship test suggests both the benefits and the limitations of trans-governmentalism. On the one hand, immigration officials' access to a wide diversity of ideas and practices in an international context has the potential to enhance efficiencies and equities in citizenship policy. On the other, officials clearly failed to invoke an institutional memory, forgetting or ignoring the positive Australian policy innovations of the previous three decades in their enthusiasm for achieving 'world's best practice'.

This failure of institutional memory in relation to immigration and citizenship policy also relates to the specific political and ideological preferences of the Howard Government. In reaching to the past, it sought only those aspects that conformed to its own essentially conservative, monocultural perspective of Australian society and history and the presumed perspective of its political 
constituency. That view precluded any consideration of Australia's rich, complex multicultural history, ${ }^{54}$ of the political dangers of enacting policies that evoked memories of the racially exclusionary practices of the past, including the White Australia Policy and the dictation test, of the failures of assimilation policies during the 1950s and early 1960s and of the specific factors that facilitated the shift to multicultural policies and a more liberal approach to citizenship.

By ignoring that history, the Howard Government effectively narrowed its perception of the political problem at hand, thereby effectively creating a 'migrant integration' problem, which many commentators did not believe existed. After all, the government never offered any tangible reasons for the reforms. There was no evidence of declining citizenship rates. The reforms did not appear to be a response to specific examples of social dislocation and ethnic unrest, an unprecedented growth in unauthorised immigration or political demands from the community. On the contrary, the strong emphasis on skills and English-language competence in contemporary Australian immigration policy suggests that, generally, migrants today can be integrated more easily than at any other point in history.

It would seem that the reforms were the outcome of a set of attitudes and preferences of a government predisposed to view Australia's ever-increasing cultural plurality in negative terms, ideologically committed to winding back some of the social and policy advances of the past 30 years and sensitive to the domestic politics of immigration, which many critics believed the government consciously manipulated for electoral advantage during its almost 12 years in office. This was despite, and perhaps because of, the fact that immigration intakes increased dramatically during the Howard years, strengthening Australia's multi-ethnic character in the process. ${ }^{55}$

These preferences self-evidently constrained the scope for constructive policy solutions to the issues of migrant integration in the early twenty-first century: rather than look to Australia's proud record of immigration reform since the 1960s and build on earlier and present-day multicultural successes, the government chose to revive aspects of the assimilationist, administrative approaches of an earlier period. The danger of this approach was that it set in place a process with the potential to repeat some of the policy failures of that era, inhibiting rather than advancing the integration process for key groups by constraining their access to citizenship. This is borne out by the release of statistics on the early impact of the test. Between 1 October 2007 and 31 March 2008, almost 20 per cent of applicants failed on their first attempt. More troubling still was the wide disparity in success rates for skilled migrants, family reunion migrants and humanitarian entrants. ${ }^{56}$ This was reinforced by a country-of-birth analysis, which showed that people from refugee-source countries and people of non-English-speaking background (from Afghanistan, Iraq, Sri Lanka and 
Sudan) had much lower application rates and higher failure rates than those from other countries. ${ }^{57}$ The reasons for the disparities are self-evident, reflecting the greater difficulties experienced by the most vulnerable among new settler groups, especially in relation to the English-language requirements.

Also significant was the evidence that citizenship applications 'plummeted' after the introduction of the test, down from 38850 in March 2007 to 16024 in March $2008 .^{58}$ Its complex requirements clearly had the potential to inhibit take-up rates, especially among the most vulnerable new settlers, further undermining the migrant integration process. This factor was undoubtedly crucial in convincing the Rudd Government to reassess the original test procedures, even though the Labor Party had supported its introduction.

Two final questions are raised by Howard's citizenship test, and my attempt here to contextualise the reforms within a broader history of Australian citizenship policy. To what extent did the government foresee the possibility that it would discriminate against specific groups, specifically refugees, the low skilled and people of non-English-speaking background, much as had occurred in the immediate postwar assimilationist period? If, as many critics suggested, the outcomes were predictable from the outset, did the government consciously set out to constrain access to citizenship rights and benefits for a significant minority of permanent settlers (and the most vulnerable of migrant groups), in contradiction of its stated objective that the aim was to enhance Australian citizenship and facilitate the integration process for all?

The possibility that citizenship laws function as a form of population gatekeeping, which regulates entry into the political community, with all its attendant benefits, if not the real physical national space, is not new, as this chapter has shown. It has, however, added salience in a world in which developed economies, including Australia, are competing for skilled and literate migrants, while attempting to limit the entry of low-skilled and illiterate or semi-literate people who are seeking better lives through emigration. This potential is reinforced in domestic and global environments in which elected governments remain preoccupied with the political consequences of their immigration policies and want to assure their electorates that they retain control of immigration intakes. Wright and others allude to this gatekeeping possibility in their recent work on citizenship tests in Europe:

Adamo and van Oers show how a standardized test, rigorously applied, is likely to exclude weak individuals who do not possess the educational and linguistic prerequisites required to pass a test. There can be no interactive support, no leeway in a written test. The cards are stacked against those with limited literacy and only basic education. We have to wonder if this is not actually part of state policy, a desired effect of the test, even if it would never be publicly acknowledged as a 
strategy...many European countries are moving towards the Australian/Canadian model of immigration, which encourages certain categories of well-qualified immigrants to fill clearly defined gaps in the skills base of the economy but bars those who would be less productive. If this is the case, tests for entry, settlement and naturalization aid European governments in encouraging literate and intellectually able citizens to migrate and settle definitively, while deterring the illiterate and the uneducated. ${ }^{59}$

If Wright is correct, what at first glance appears to have been the Howard Government's neglect of Australia's failed and discriminatory citizenship policies of an earlier era could in fact have been their wilful invocation. By 2006, the government was firmly caught between its neo-liberal commitment to large-scale economic migration and its much-touted social-conservative opposition to multiculturalism - and, likewise, between its repeated public pledge that immigration served an overwhelming economic good and the practical impossibility of completely excluding 'less-desirable' migrants such as refugees, the low skilled and the non-English speaking. In this context, the introduction of the citizenship test with its attendant emphasis on language skills, knowledge of core values and administrative complexity might have been intended to assert the privileged status of skilled, English-speaking migrants and, in a more practical sense, to discourage and inhibit the entry of less-desirable migrants into the Australian political community, even if their physical exclusion from the nation-state was not possible (or even desirable). It also aimed to send a powerful message to the electorate that the government retained firm control over the character of the national community, even if real control over immigration numbers had long ago been ceded.

\section{Conclusion}

The Howard Government's citizenship test reflected a deeply problematic model of citizenship that was always unlikely to achieve the desired result of enhancing the status of Australian citizenship and encouraging the integration process for all migrants. It relied on notoriously vague concepts such as 'the national community' and 'way of life' to sell the citizenship message. It embodied a monocultural, undifferentiated and exclusionary view of the Australian national community and Australian history that privileged white, male, 'British-Australian' institutions and endeavours and neither reflected nor responded adequately to Australia's multicultural, globalised reality. It set in place highly complex linguistic and administrative procedures that from the outset discriminated against the low skilled and those with poor English skills.

Despite the Howard Government's professed respect for the values and traditions of the past, the test embodied a highly selective form of social remembering that 
pointedly ignored the lessons of the past and had the potential to repeat some of the policy failures of an earlier assimilationist era. This chapter has raised the possibility that perhaps, after all, this was the government's true intention, using the citizenship test as a political tool to keep potentially disaffected voters onside, and also as a practical means of inhibiting entry into the political community of those people perceived as less-desirable settlers. It is too soon to say whether the Rudd Government's reforms will tangibly improve Australia's citizenship regime. In any case, the message is clear: if governments are serious about migrant rights and equity, they need to engage with Australia's past record on citizenship and migrant settlement, acknowledge and embrace the positive policy advances of the past four decades, look beyond merely cultural-nationalist and economic considerations in regards to citizenship and focus anew on questions of social justice, equity and respect for difference.

\section{Acknowledgments}

Versions of this paper were presented at a seminar at the Institute for Social Research, Swinburne University of Technology and the Governing by Looking Back conference at The Australian National University (both in December 2007). My thanks to Klaus Neumann and all participants for their valuable feedback.

\section{Endnotes}

${ }^{1}$ Kevin Andrews, Commonwealth Parliamentary Debates [hereafter CPD], Representatives, 30 May 2007, p. 6, <www.aph.gov.au/hansard/reps/dailys/dr300507.pdf>

2 A Newspoll survey conducted on 22-24 September 2006 indicated that 77 per cent of respondents were in favour of the proposed citizenship test and 53 per cent strongly in favour (<www.newspoll.com.au/cgi-bin/polling/display_poll_data.pl $>$ ).

3 Summary report on the outcomes of the public consultation on the merits of introducing a formal citizenship test, < http://pandora.nla.gov.au/pan/31543/20070124-0000/www.minister.immi.gov.au/ parlsec/media/responses/citizenship-test/summary_report_citizen_test_paper.pdf>

4 Butterly, Nick 2008, 'Migrants flunk citizenship tests', Age, 2 January 2008.

5 Berkovic, Nicola 2008, 'Howard's migrant test to be dumped', Australian, 22 November 2008.

6 Brändström, Annika, Bynander, Frederik and 't Hart, Paul 2004, 'Governing by looking back: historical analogies and crisis management', Public Administration, vol. 82, no. 1, pp. 191-210. See also Olick, Jeffrey K. and Robbins, Joyce 1998, 'Social memory studies: from "collective memory" to the historical sociology of mnemonic practices', Annual Review of Sociology, vol. 24, pp. 105-40.

7 Department of Immigration and Citizenship, History of the citizenship test, <www.citizenship.gov.au/test/background/history.htm>

8 Australian Citizenship Act 2007, s. 21, as amended by Act No. 142 of 2007.

9 Commonwealth of Australia 2007, Becoming an Australian Citizen, September 2007, Reprinted with corrections November 2007, p. 43, <http://pandora.nla.gov.au/pan/53892/20081109-0018/ www.citizenship.gov.au/test/resource-booklet/citz-booklet-full-ver.pdf>

10 Commonwealth of Australia 2006, Australian Citizenship: Much more than a ceremony, 17 September 2006, p. 12, <http://pandora.nla.gov.au/pan/64133/20061005-0000/ www.citizenship.gov.au/news/DIMA_Citizenship_Discussion_Paper.pdf>

${ }^{11}$ Ruddock, Philip 1998, Australian Citizenship Council announced, Press release MPS104/98, 7 August 1998, <http://www.multiculturalaustralia.edu.au/doc/immdept_1.pdf>

12 Commonwealth of Australia 2001, Australian Citizenship... A Common Bond: Government response to the report of the Australian Citizenship Council, May 2001, p. 4,

$<$ http://pandora.nla.gov.au/pan/53892/20070509-0000/www.citizenship.gov.au/_pdf/0501report.pdf> 


\section{Does History Matter?}

13 Commonwealth of Australia, Australian Citizenship: Much more than a ceremony, p. 8.

14 Commonwealth of Australia, Becoming an Australian Citizen, p. 1.

15 The 'privileges' include the right to vote, to seek election to Parliament, to apply for a passport, consular assistance and employment in the defence services. The responsibilities include voting, serving on a jury and defending Australia should the need arise (ibid., pp. 3-4).

16 Dutton, David 2002, One of Us? A century of Australian citizenship, UNSW Press, Sydney, especially chs 1 and 9.

17 Commonwealth of Australia, Becoming an Australian Citizen, pp. 14-16.

18 Tavan, Gwenda 2008, 'Multiple choice time for Labor', Age, 10 January 2008.

19 Commonwealth of Australia, Becoming an Australian Citizen, p. 7.

20 Howard, John 2006, Australia Day address to National Press Club, 25 January 2006,

<http://pandora.nla.gov.au/pan/21243/20061016-0000/www.australianpolitics.com/news/2006/01/ 06-01-25_howard.html>

21 Hage, Ghassan 1998, White Nation: Fantasies of white supremacy in a multicultural society, Pluto, Sydney, pp. 42-7.

22 Judith Bond, 'Letter to the editor', Age, 3 January 2008.

23 Hamilton, Paula 1994, 'The knife edge: debates about memory and history', in Kate Darian-Smith and Paula Hamilton (eds), Memory and History in Twentieth Century Australia, Oxford University Press, Melbourne, p. 23.

24 Olick and Robbins, 'Social memory studies', p. 117.

25 Macintyre, Stuart and Clark, Anna 2003, The History Wars, Melbourne University Press, Melbourne.

26 Curran, James 2004, The Power of Speech: Australian prime ministers defining the national image, Melbourne University Press, Melbourne.

27 Davidson, Alastair 1997, From Subject to Citizen: Australian citizenship in the twentieth century, Cambridge University Press, Cambridge, pp. 45-6.

28 Taylor, Tony 2008, 'Howard's way fails school test', Age, 14 January 2008.

29 Hirst, John 2008, 'Australia: the official history', Monthly, February 2008, p. 31.

30 Ibid., p. 31.

31 Ibid., p. 35.

32 Ibid., p. 35.

33 Commonwealth of Australia, Becoming an Australian Citizen, pp. 32-3.

34 Hirst, 'Australia', pp. 34-5.

35 Commonwealth of Australia, Becoming an Australian Citizen, p. 7.

36 John Howard, quoted in Brett, Judith 2005, Relaxed and Comfortable: The Liberal Party's Australia, Black Inc., Melbourne, p. 29. See also Elder, Catriona 2007, Being Australian: Narratives of national identity, Allen \& Unwin, Sydney, especially ch. 1.

37 Georgiou, Petro 2007, Australian citizenship in the 21st century, Paper delivered to CO.AS.IT. Italian Assistance Association, 14 March 2007. An edited extract was published as 'A needless test for citizenship', Canberra Times, 16 March 2007. Reports of the speech were published in the Age, Sydney Morning Herald, Australian and Herald Sun on 15 March 2007. See also Petro Georgiou, CPD, Representatives, 8 August 2007, pp. 29-34, <www.aph.gov.au/hansard/reps/dailys/dr080807.pdf>

38 Howard praised the Australian Greek community in 2006, citing it as an example of a community that had integrated well. The irony is that the Greek community has relatively low rates of English-language proficiency compared with other groups; see van Vliet, Peter 2006, 'Diversity is a fact, not a doctrine', Age, 29 November 2006.

39 Dutton, One of Us?; Davidson, From Subject to Citizen.

40 Holland, Alison (forthcoming), 'Australian citizenship in the twenty-first century: historical perspectives', in Christina Slade and Martina Mollering (eds), From Migrant to Citizen: Testing language, testing culture, Palgrave Macmillan, New York.

41 Chesterman, John and Galligan, Brian (eds) 1999, Defining Australian Citizenship: Selected documents, Melbourne University Press, Melbourne, p. 62.

42 Ibid., pp. 28-9, 32-6.

43 Tavan, Gwenda 1997, “"Good neighbours": community organisations, migrant assimilation and Australian society and culture, 1950-1961', Australian Historical Studies, vol. 109, pp. 77-89; 
Haebich, Anna 2008, Spinning the Dream: Assimilation in Australia 1950-1970, Fremantle Press, Fremantle, especially chs 3 and 4 .

44 Department of Immigration, 'Naturalization of aliens', 6 December 1945, National Archives of Australia, CP815/1, 29/021/53.

45 Ibid.

46 Jordens, Ann-Mari 1997, Alien to Citizen: Settling migrants in Australia 1945-75, Allen \& Unwin, Sydney, pp. 175, 183.

47 Ibid., p. 175.

48 Davidson, From Subject to Citizen, p. 256.

49 Galligan, Brian and Roberts, Winsome 2004, Australian Citizenship, Melbourne University Press, Carlton, p. 95.

50 Commonwealth of Australia, Australian Citizenship: Much more than a ceremony, p. 9.

51 Countries with citizenship tests today include the United States, the United Kingdom, Canada, Denmark, the Netherlands and Germany. Testing content and procedures vary widely. The United Kingdom, for example, has opted for a test that puts less emphasis on history and cultural integration and more on knowledge of practical day-to-day affairs. The Netherlands, in contrast, requires even prospective residents to formally pledge to uphold 'Dutch values' in its attempt to ensure maximum 'cultural assimilation'. Wright, Sue 2008, 'Citizenship tests in Europe-editorial introduction', International Journal on Multicultural Societies, vol. 10, no. 1, pp. 1-2, 5-7.

52 Castles, Stephen J. and Miller, Mark J. 2003, The Age of Migration: International population movements in the modern world, 3rd edn, Guilford, New York, especially Introduction, chs 4 and 5 and Conclusion. 53 Wright, 'Citizenship tests in Europe', p. 7.

54 Hodge, Bob and O'Carroll, John 2006, Borderwork in Multicultural Australia, Allen \& Unwin, Sydney, especially ch. 4.

55 Annual immigration intakes rose from approximately 82000 at the start of the Howard era in 1996 to 159000 by its end in 2007.

56 The percentage of applicants who passed the test on their first or subsequent attempt was 99 per cent for skilled stream clients, 91 per cent for family stream clients and 82 per cent for humanitarian program clients. An examination of the average number of tests per client shows that while skilled stream applicants average about 1.1 tests each, the figure is 1.2 for family stream and a significant 1.7 for humanitarian stream clients. Department of Immigration and Citizenship 2008, Australian Citizenship Test: Snapshot report, March 2008, pp. 3-5 (copy provided to the author by a private source).

57 Ibid., p. 6.

58 Topsfield, Jewel 2008, 'Citizenship test "spooks" many would-be Aussies', Age, 29 April 2008.

59 Wright, 'Citizenship tests in Europe', pp. 4-5. 